This manuscript version is made available under the CC-BY-NC-ND 4.0

license http://creativecommons.org/licenses/by-nc-nd/4.0/

\title{
Groundwater arsenic contamination in Burkina Faso, West Africa: Predicting and verifying regions at risk
}

Anja Bretzler*1,4 ${ }^{\text {, Franck Lalanne }}{ }^{2}$, Julien Nikiema ${ }^{3}$, Joel Podgorski ${ }^{1}$, Numa Pfenninger ${ }^{1}$, Michael Berg ${ }^{1}$, Mario Schirmer ${ }^{1,4}$

${ }^{1}$ Eawag: Swiss Federal Institute of Aquatic Science and Technology, Dübendorf, Switzerland

${ }^{2}$ Institut International d'Ingénierie de l'Eau et de l'Environnement (2iE), Ouagadougou, Burkina Faso

${ }^{3}$ Université Ouaga I Pr. Joseph KI-ZERBO, Ouagadougou, Burkina Faso

${ }^{4}$ Centre d'Hydrogéologie et de Géothermie (CHYN), Université de Neuchâtel, Switzerland

*Corresponding author : anja.bretzler@eawag.ch

\section{Abstract}

Arsenic contamination in groundwater from crystalline basement rocks in West Africa has only been documented in isolated areas and presents a serious health threat in a region already facing multiple challenges related to water quality and scarcity. We present a comprehensive dataset of arsenic concentrations from drinking water wells in rural Burkina Faso $(n=1498)$, of which $14.6 \%$ are above $10 \mu \mathrm{g} / \mathrm{L}$. Included in this dataset are 269 new samples from regions where no published water quality data existed. We used multivariate logistic regression with arsenic measurements as calibration data and maps of geology and mineral deposits as independent predictor variables to create arsenic prediction models at concentration thresholds of 5,10 and $50 \mu \mathrm{g} / \mathrm{L}$. These hazard maps delineate areas vulnerable to groundwater arsenic contamination in Burkina Faso. Bedrock composed of schists and volcanic rocks of the Birimian formation, potentially harbouring arsenic-containing sulphide minerals, has the highest probability of yielding groundwater arsenic concentrations $>10$ $\mu \mathrm{g} / \mathrm{L}$. Combined with population density estimates, the arsenic prediction models indicate that 560,000 people are potentially exposed to arsenic-contaminated groundwater in Burkina Faso. The same geological formations that are positive predictors for elevated arsenic concentrations in Burkina Faso also exist in neighbouring countries such as Mali, Ghana and Ivory Coast. This study's results are thus of transboundary relevance and can act as a trigger for targeted water quality surveys and mitigation efforts.

Keywords: arsenic contamination, drinking water, West Africa, hazard modelling, health threat

\section{Introduction}

Despite the increased construction and development of centralised water distribution systems and piped water supplies in sub-Saharan Africa during the last decades, small-scale groundwater abstraction via hand-dug wells or village hand pumps is often the sole source of drinking water for 
rural populations (MacDonald et al., 2009; Martin \& Van De Giesen, 2005). Especially in the arid and semi-arid regions of the Sahel belt, where surface water resources can dry out completely in the long dry season, rural areas rely on groundwater for their drinking water supply (Edmunds, 2008). In general, groundwater is regarded as having good drinking water quality and to be predominantly free of pathogens, but chemical constituents may present a hazard that is often discovered late or not at all due to insufficient testing and surveying of water quality (MacDonald \& Calow, 2009; UNICEF, 2008).

This is the case for arsenic, which can occur naturally in groundwater in concentrations that can lead to serious and chronic health effects after prolonged consumption (Naujokas et al., 2013). Arsenic exposure has not only been linked to the development of a variety of cancers, but also to developmental, neurological, respiratory and cardiovascular effects (Argos et al., 2010; Naujokas et al., 2013; Yuan et al., 2010; Yuan et al., 2007). The World Health Organisation (WHO) has imposed a drinking water guideline concentration for arsenic of $10 \mu \mathrm{g} / \mathrm{L}$, which has also been adopted by Burkina Faso (MAHRH/MS, 2005; WHO, 2011). Large scale geogenic contamination of groundwater with arsenic in south-east Asia (e.g. Bangladesh, India, Cambodia, Vietnam) has received a lot of attention in the last two decades (e.g. Bhattacharya et al. (1997); Flanagan et al. (2012); Smith et al. (2000), Berg et al. (2007)). The phenomenon is still relatively unknown and little studied in West Africa though (Ahoulé et al., 2015), where fractured aquifers composed of weathered crystalline bedrock predominate. This is a totally different system to the young sedimentary aquifers of arsenicaffected regions in Asia, where arsenic is released by reductive dissolution (Ahmed et al., 2004). Studies in Ghana and Burkina Faso have shown that the oxidation of arsenic-containing sulphide minerals found in rocks of the Birimian formation is the initial process responsible for high arsenic levels found in some groundwater (Asante et al., 2007; Barro-Traoré et al., 2008; Buamah et al., 2008; Sako et al., 2016; Smedley, 1996; Smedley et al., 2007; Somé et al., 2012). However, an understanding of the extent of the problem and a detailed investigation of the sources and geological conditions leading to arsenic contamination is currently lacking.

Since testing wells for arsenic contamination is expensive and time consuming, maps identifying areas that are especially vulnerable to this kind of pollution are largely missing. However, they would be a useful tool for decision makers by helping to focus efforts where they are most needed. Such groundwater vulnerability assessment and mapping is a growing field, with more and more studies focussing on finding methods to assess the vulnerability of aquifers to contaminants such as nitrate or pesticides (Nolan \& Hitt, 2006; Nolan et al., 2002; Ouedraogo et al., 2016; Sorichetta et al., 2013).

Specifically concerning arsenic, statistical modelling to predict the spatial occurrence of arsenic and highlight areas where safe drinking water predominates has been performed successfully at different 
scales, from global to regional, and in a range of different geological terrains (Ahn \& Cho, 2013; Amini et al., 2008; Ayotte et al., 2016; Ayotte et al., 2006; Dummer et al., 2015; Rodríguez-Lado et al., 2013; Shamsudduha et al., 2015; Winkel et al., 2008; Winkel et al., 2011; Yang et al., 2012). Fundamental to the development of such models is knowledge of the geochemical processes leading to the occurrence of high arsenic in groundwater, as well as finding the predictor variables (proxies) to explain these. Since geogenic arsenic is by definition of geological origin, such proxies are usually geological variables, but various environmental parameters, such as temperature or precipitation, that influence geochemical processes in groundwater may also be relevant (Amini et al., 2008).

The concentration of arsenic in groundwater is not only related to the abundance of arsenic found in minerals in the aquifer matrix, it is also a function of solubility, which is governed predominantly by pH and redox conditions (Dixit \& Hering, 2003; Hug \& Leupin, 2003). In China, for example, Rodríguez-Lado et al. (2013) found elevated groundwater arsenic concentrations in sedimentary basins and river valleys to be strongly associated with Holocene sediments, soil salinity, fine subsoil texture and an elevated Topographic Wetness Index, which functioned as proxies for chemically reducing environments with high arsenic solubility. In the case of arsenic release due to sulphide mineral oxidation in crystalline basement rocks, different proxies must be taken into account, as has been shown by Ayotte et al. (2006), Yang et al. (2012), Ahn and Cho (2013) and Dummer et al. (2015) who modelled a positive correlation between arsenic occurrence and certain mineral-bearing geological formations.

The goal of this study is to investigate the distribution and magnitude of geogenic groundwater arsenic concentrations in Burkina Faso in order to better identify affected areas and populations. We carried out a country-wide arsenic survey and created arsenic prediction models based on three different concentration thresholds $(5,10$ and $50 \mu \mathrm{g} / \mathrm{L})$ taking into account the geochemical processes and conditions responsible for elevated arsenic in groundwater in West Africa. The models were calibrated using a spatially limited arsenic measurement dataset and then validated with measurements from other regions in Burkina Faso to ensure country-wide validity. As is often the case in developing countries, datasets of physical parameters such as geology, hydrogeology, mineral resources and climate were not available to the same extent or resolution as in industrialised nations. For this study, only surface parameters were available. The depth of individual boreholes and lithological logs were not available. Therefore, another goal of this study was to investigate whether a reliable hazard model for arsenic can be produced in light of data scarcity. Due to the large number of countries in the West African region and the difficulty in collecting the necessary data for each individual country, we chose a single "model" country for which to create arsenic prediction models. Burkina Faso was selected because some existing studies already show elevated 
groundwater arsenic but are limited in their spatial extent (Barro-Traoré et al., 2008; COWI, 2004; Nzihou et al., 2013; Ouédraogo \& Amyot, 2013; Smedley et al., 2007; Somé et al., 2012). The same geological formations that harbour arsenic-containing sulphide minerals in Burkina Faso are also found in neighbouring countries such as Mali, Niger, Ivory Coast, Ghana and Benin (Schlüter, 2008). Therefore, this study is relevant to the greater West African region and should spur increased discussion and mitigation efforts concerning arsenic contamination and its health effects.

\section{Hydrological and geological setting and its relevance to elevated arsenic concentrations}

Burkina Faso has a hot and dry semi-arid climate, with rainfall restricted to one rainy season per year from June to September. Rainfall is higher in the south-west than in the more arid north and east. Groundwater recharge occurs during the rainy season with smaller total amounts in the north than in the south-west, but can be spatially highly heterogenous (Filippi et al., 1990; Martin \& Van De Giesen, 2005). Geomorphologically, Burkina Faso is relatively flat, with most of the country lying between 250 and 400 m a.s.l. (Fig. 1). 65 \% of the land area of Burkina Faso is covered by the Volta basin and is drained by the Mouhoun, Nazinon and Nakambé rivers (Black, Red and White Volta) (Martin \& Van De Giesen, 2005).

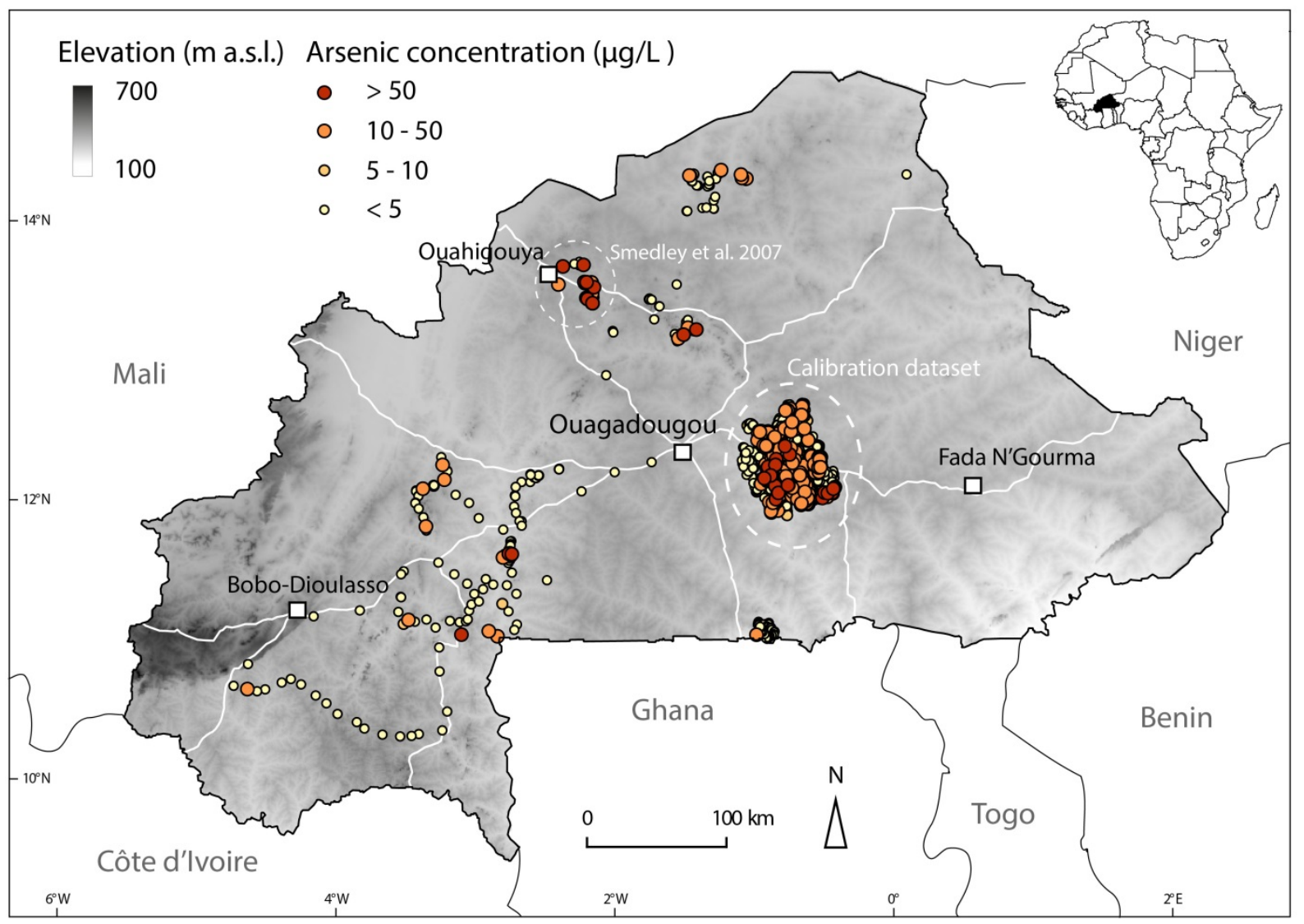


Fig. 1: Overview of the study area, giving the location of groundwater arsenic measurements used in this study $(n=1498)$. The calibration dataset (source: Unicef/BUMIGEB) is represented by the large cluster of points east of Ouagadougou ( $n=1184)$. The remaining points comprise the validation dataset $(n=314)$, which includes data from Smedley et al. (2007) $(n=45)$ and the new measurements presented in this study $(n=269)$.

Between the in-tact crystalline bedrock at depth and the ground surface, a typical tropical hard-rock weathering profile exists and controls the local hydrogeological properties, explained in more detail in Courtois et al. (2010) and Nikiema et al. (2013). The top few metres of the ground surface are usually composed of a laterite crust, underlain by a few tens of metres of weathered clayey saprolite, which represents the upper part of the aquifer. This then merges into the so-called fissured layer (densely fissured and fractured weathered bedrock), which can extend to a depth of 80-100 metres below ground level and acts as the main aquifer for groundwater storage (Courtois et al., 2010). In rural areas, boreholes for drinking water abstraction with hand pumps are drilled into the fissured layer and have depths ranging from 35-90 metres. Hand-dug wells tapping shallower aquifers in the weathered saprolite layer may also be used for drinking water purposes.

A large part of Burkina Faso is covered by Paleoproterozoic crystalline basement rocks. These comprise belts of (meta-)volcanic, metasedimentary and plutonic rocks of the Birimian Formation, as well as large intrusive bodies of Eburnean granitoids (granite, tonalite, granodiorite) (Fig. 2). The Birimian volcano-sedimentary belts (also known as Birimian greenstone belts) were formed as part of an island-arc system between 2240 and $2170 \mathrm{Ma}$. They are composed of varied volcanic and plutonic rocks, including basalt, andesite, rhyolite and gabbro, that occur next to schists, quartzite and chert (Castaing et al., 2003a). The Birimian formation has undergone considerable mineralisation which was synchronous with regional metamorphism and deformation. This lead to the formation of highgrade ore deposits, primarily gold and to a lesser extent other metallic ores. Gold deposits principally occur within or adjacent to quartz veins that formed later than the host rock (Béziat et al., 2008). Native gold can occur directly within deformed quartz veins, or as gold particles disseminated in the alteration halos of unfolded quartz veins. Both mineralisation types are directly associated with the occurrence of sulphide minerals such as pyrite $\left(\mathrm{FeS}_{2}\right)$ and arsenopyrite (FeAsS) (Béziat et al., 2008; Bourges et al., 1998; Castaing et al., 2003a). Pyrite can incorporate minor and trace elements into its mineral structure and arsenic concentrations in pyrite can occur up to $10 \mathrm{wt} \%$ (Abraitis et al., 2004). The oxidation of such sulphide minerals when in contact with oxygen-containing groundwater and subsequent release of arsenic to solution can lead to considerably elevated groundwater arsenic concentrations (Verplanck et al., 2008; Walker et al., 2006; Yang et al., 2015). In general, depending on the redox conditions in the subsurface, arsenic should stay in solution in its reduced form As(III) if 
reducing conditions are prevalent, but should be tightly adsorbed to iron hydroxides if conditions are oxidising (Dixit \& Hering, 2003). Nevertheless, Smedley et al. (2007) measured clearly elevated arsenic concentrations in oxidising groundwater in Burkina Faso and hypothesised that these high concentrations occur in the direct vicinity of mineralised zones where the arsenic loading in groundwater can be very high locally.

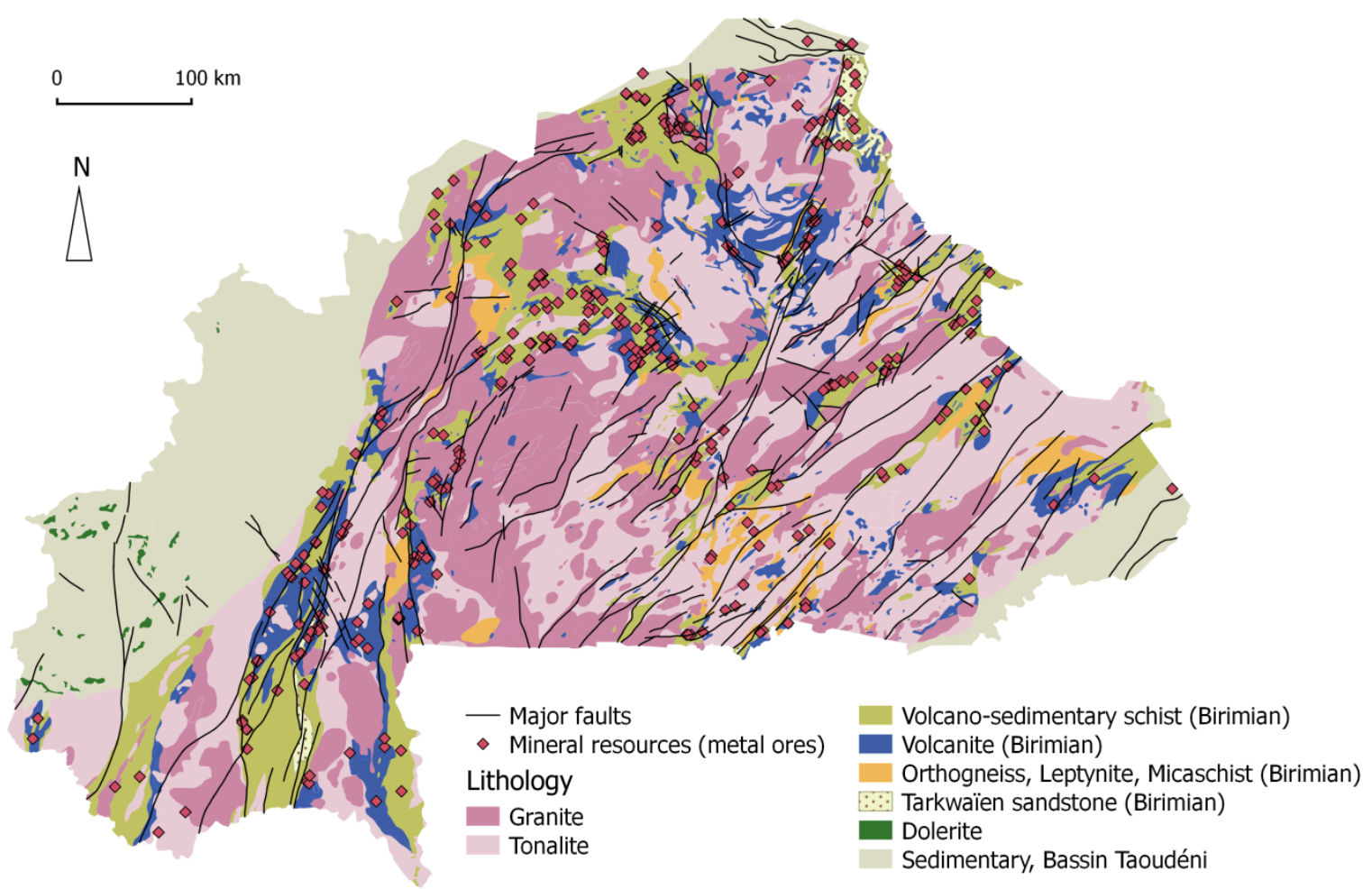

Fig. 2: Simplified geological map of Burkina Faso, showing the main rock types, major faults and the location of mineral deposits (metal ores). Modified from Castaing et al. (2003b)

\section{Methods}

\subsection{Data collection}

\subsubsection{Arsenic concentration measurements}

A dataset $(n=1498)$ of georeferenced groundwater arsenic concentration measurements from boreholes in rural areas was used in this study (Fig. 1 to calibrate and validate the arsenic prediction model. The dataset includes both new and existing data (Table 1). Included in the 1498 measurements are 269 new groundwater samples taken specifically for this study from 2014 to 2016 in different regions of Burkina Faso (Table 1, Fig. 1). Samples originate from village boreholes 
equipped with hand pumps (types India, Volanta or Vergnet). We followed standard sampling and laboratory analysis procedures as described in similar studies (Berg et al., 2008; Buschmann et al., 2007). On-site parameters (temperature, $\mathrm{pH}$, electrical conductivity, $\mathrm{O}_{2}$ concentration and redox potential) were measured in a flow-through cell connected to the pump spout. Water sampling was performed after on-site parameters had stabilised, generally after 5-10 minutes. All sampled boreholes are pumped nearly continuously during the day by local residents for drinking water production, hence water was never stagnant in the pipes during sampling. Samples for major cations and minor and trace element analysis (including arsenic) were collected in acid-washed polypropylene bottles, filtered through $0.45 \mu \mathrm{m}$ filters and acidified with concentrated $\mathrm{HNO}_{3}$ suprapure to a $\mathrm{pH}<2$. An unfiltered, non-acidified aliquot was collected for analysis of anions, DOC and TIC. Samples were stored below $4^{\circ} \mathrm{C}$ whenever possible. Analysis was performed in the laboratories of Eawag, Switzerland, using ICP-MS (Agilent 7500 cx) for cations and trace elements, ion chromatography for anions (ICS-2001 Dionex) and a carbon analyser (TOC Shimadzu) for TIC and DOC.

Also included in the total dataset of 1498 samples are1184 arsenic measurements obtained through a study commissioned by Unicef Burkina Faso and carried out by the Bureau des Mines et de la Géologie du Burkina (BUMIGEB) in 2010 to measure arsenic concentrations in drinking water boreholes in the province of Ganzourgou, $50 \mathrm{~km}$ east of Ouagadougou. Samples were measured in the laboratories of BUMIGEB using Atomic Absorption Spectroscopy (AAS). Depths of individual boreholes are not known, however a separate database of 434 boreholes from the province of Ganzourgou contains depths ranging from 35 to 90 metres, with a mean of 51 metres. In addition to the Ganzourgou data, 45 arsenic measurements from the Ouahigouya region (Yatenga province) in northern Burkina Faso were provided by Smedley et al. (2007).

Table 1: Arsenic concentration measurements $(n=1498)$ used for model calibration and validation

\begin{tabular}{|lllll|}
\hline & Province & No. of samples & $\%>10 \mu \mathrm{g} / \mathrm{L}$ As & Source \\
\hline Calibration data & Ganzourgou & 1184 & $15.5 \%$ & Unicef/BUMIGEB \\
\hline Validation data & Yatenga & 45 & $42 \% *$ & Smedley et al., 2007 \\
& Nahouri & 52 & $2 \%$ & This study \\
& Soum & 38 & $13 \%$ & This study \\
& Balé & 31 & $16 \%$ & This study \\
& Various (South-West) & 101 & $9 \%$ & This study \\
& 22 & $14 \%$ & This study \\
& Bam & 15 & $0 \%$ & This study \\
& Boulkiemdé & 10 & $20 \%$ & This study \\
\hline
\end{tabular}

* Non-random sampling specifically targeting arsenic-affected boreholes 


\subsubsection{Model variables}

\subsubsection{Independent predictor variables}

199 Georeferenced spatial data with a country-wide coverage were considered as predictor variables for 200 the arsenic prediction model. As groundwater arsenic in Burkina Faso is thought to originate from 201 sulphide minerals in mineralised zones, focus was set on assembling predictor variables that possibly 202 indicate such mineralisation, such as lithological variables and distances to mineral deposits, faults 203 and granitic intrusions (Table 2). The Geological and Mineral Deposit Map of Burkina Faso at a scale 204 of 1:1,000,000 (Castaing et al., 2003b) was used to extract major lithologies, faults and the location 205 of mineral deposits of metal ores (e.g. gold, zinc, chromium, manganese) (Fig. 2). . In addition to the 206 location of mineralised zones, groundwater flow and residence time may also play a role in arsenic 207 concentrations. Due to the heterogeneity of fractured bedrock aquifers, mapping such parameters 208 on a regional or country-wide scale is problematic (Dewandel et al., 2012). As possible proxies for 209 hydrological processes related to groundwater flow and residence time we chose the "drainage direction" and "flow accumulation" datasets of the Hydrosheds database (Lehner et al., 2008). These data are derived from the digital elevation model (DEM) of the Shuttle Radar Topography Mission (SRTM).

Table 2: Predictor variables used in the arsenic prediction model

\begin{tabular}{|l|r|l|l|}
\hline Predictor variables & Type & Format & Source \\
\hline Lithology & Categorical & Polygon & BUMIGEB/BRGM \\
Volcano-sedimentary schist (Birimian) & Categorical & Polygon & (Castaing et al., 2003b) \\
Volcanite: basalt, andesite, rhyolite (Birimian) & Categorical & Polygon & \\
Orthogneiss (Birimian) & Categorical & Polygon & \\
Granite & Categorical & Polygon & \\
Tonalite & Continuous & Raster & \\
Distance to faults & Continuous & Raster & \\
Distance to mineral deposits (metal ores) & Continuous & Raster & \\
\cline { 2 - 4 } Distance to granitoid rocks & Continuous (30 arc seconds) & Raster & HydroSHEDS/WWF, \\
Drainage direction & Continuous (30 arc seconds) & Raster & (Lehner et al., 2008) \\
Flow accumulation & &
\end{tabular}


The predictor data layers were converted to raster format (if originally in vector format such as polygon, line or point) with a resolution of 30 arc seconds ( $1 \mathrm{~km}$ on the equator) using standard tools available in the open source QGIS and GRASS software packages (GRASS Development Team, 2015; QGIS Development Team, 2015). The distances to faults, mineral deposits, and granitoid rocks were calculated within a buffer zone of a maximum of $10 \mathrm{~km}$ away from the feature.

\subsubsection{Dependent variable (arsenic concentration measurements)}

224

In order to be compatible with the predictor variables, the calibration dataset of arsenic concentration measurements was converted from point to raster format and concentrations aggregated to one value per $1 \mathrm{~km}^{2}$ pixel by using the maximum arsenic concentration if more than one measurement fell into the pixel. We chose the more conservative maximum value instead of averaging concentrations in order to make sure that high-arsenic boreholes remain in our analyses and are not "diluted" by surrounding low concentrations. As such, the original calibration dataset of 1184 individual arsenic measurements was reduced to 877 measurements, with 39\% above $5 \mu \mathrm{g} / \mathrm{L}$, $19 \%$ above $10 \mu \mathrm{g} / \mathrm{L}$ and $2 \%$ above $50 \mu \mathrm{g} / \mathrm{L}$. The aggregated concentration values were binary-coded according to the chosen threshold (above threshold $=1$, below threshold $=0$ ) and used as the dependent variable in the logistic regression model. We chose the threshold values of 5, 10 and 50 $\mu \mathrm{g} / \mathrm{L}$ to represent the full concentration range of the dataset. Furthermore, $10 \mu \mathrm{g} / \mathrm{L}$ is the WHO and national drinking water guideline value and therefore of greatest relevance for drinking water. Discussions also exist in Burkina Faso of raising the guideline value to $50 \mu \mathrm{g} / \mathrm{L}$, a value that is used in some other arsenic-affected countries, such as Bangladesh. The calibration dataset from Ganzourgou province has a limited spatial extent $\left(4000 \mathrm{~km}^{2}\right)$ but very dense borehole coverage within this area. All predictor variables are present in this zone, any potential spatial bias is therefore limited. The validation dataset on the other hand (composed of the 269 new samples described in this study, plus 45 samples from Smedley at al. (2007)), is spatially well distributed and includes locations from the north, south and west of Burkina Faso (Fig. 1).

\subsection{Geospatial hazard modelling}

Logistic regression was used to model the probability of arsenic occurring over three concentration threshold values. This method is extensively used in a variety of fields to determine the relationship 
between a binary dependent outcome variable and a number of independent predictor variables (Hosmer et al., 2013). Specifically, logistic regression models the log(odds), which is defined as the probability $P$ that an event occurs relative to the probability that it fails to occur $(1-P)$, (e.g. arsenic being above/below the threshold concentration), as the linear combination of a set of independent predictor variables $\left(x_{1} . . x_{k}\right)$ with model coefficients $\beta_{1} . . \beta_{k}$ (Hosmer et al., 2013).

$$
\log (\text { odds })=\log \left(\frac{P}{1-P}\right)=\beta_{0}+\beta_{1} x_{1}+\ldots+\beta_{k} x_{k}
$$

Removing the logarithm then gives the probability:

$$
P=\frac{e^{\left(\beta_{0}+\beta_{1} x_{1}+\ldots+\beta_{k} x_{k}\right)}}{1+e^{\left(\beta_{0}+\beta_{1} x_{1}+\ldots+\beta_{k} x_{k}\right)}}
$$

The exponential of the model coefficients $\exp (\beta)$ being greater than 1 indicates an increasing effect of the predictor variable on the dependent variable, while a value less than 1 denotes a decreasing effect.

Logistic regression modelling was carried out within the $R$ statistical environment ( $R$ Core Team, 2015). We have followed similar procedures as described in detail in Rodríguez-Lado et al. (2013). Univariate logistic regressions for the three chosen thresholds of 5, 10 and $50 \mu \mathrm{g} / \mathrm{L}$ were performed separately on each predictor variable using the whole calibration dataset as the dependant variable. The drainage direction and flow accumulation datasets were discarded from further analyses as they did not prove to be significant predictors for elevated arsenic at the 95\%-confidence level in the univariate models ( $p$-values $>0.05$ ) (Table 3 ). The orthogneiss, tonalite and "distance to faults" predictors were also not significant (Table 3), but were nevertheless kept for further analyses. Orthogneiss belongs to the partly mineralised Birimian formation and could potentially be linked to arsenic contamination, tonalite is a widespread rock type in Burkina Faso with a large spatial coverage (Fig. 2) and fault zones as areas of increased fracturing and/or deformation are also hypothesised to be potential proxies for mineralised zones. 
Table 3: Results of univariate logistic regression models for three concentration thresholds. Significant values at

276 the 95\%-confidence level $(p<0.05)$ are highlighted in bold font

\begin{tabular}{|lccc|}
\hline Predictor variables & \multicolumn{3}{c|}{ p-values } \\
\hline & $\mathbf{5} \boldsymbol{\mu g} / \mathrm{L}$ & $\mathbf{1 0} \boldsymbol{\mu g} / \mathbf{L}$ & $\mathbf{5 0} \boldsymbol{\mu g} / \mathbf{L}$ \\
\hline Volcano-sedimentary schist (Birimian) & $<0.001$ & $<0.001$ & $<0.001$ \\
Volcanite: basalt, andesite, rhyolite (Birimian) & $\mathbf{0 . 0 1}$ & $<\mathbf{0 . 0 0 1}$ & 0.99 \\
Orthogneiss (Birimian) & 0.22 & 0.15 & 0.99 \\
Granite & $\mathbf{0 . 0 0 2}$ & $<\mathbf{0 . 0 0 1}$ & $\mathbf{0 . 0 1}$ \\
Tonalite & 0.40 & 0.06 & 0.44 \\
Distance to faults & 0.67 & 0.42 & 0.19 \\
Distance to mineral deposits (metal ores) & $<0.001$ & 0.87 & $\mathbf{0 . 0 2}$ \\
Distance to granitoid rocks & $<0.001$ & $<0.001$ & $<0.001$ \\
Drainage direction & 0.14 & 0.63 & 0.31 \\
Flow accumulation & 0.59 & 0.81 & 0.93 \\
\hline
\end{tabular}

The remaining eight predictor variables were used for multivariate logistic regression. Instead of single-algorithm models, which are vulnerable to the number and location of the calibration data, we chose to create an ensemble model from numerous base models (ensemble members) for more robust results (Rodríguez-Lado et al., 2013). The calibration dataset was randomly split into training (75\%) and testing (25\%) portions for multivariate logistic regression with stepwise selection (both directions), whereby predictor variables are automatically retained or removed according to the Akaike Information Criterion (AIC) (Akaike, 1974). This procedure was repeated 100 times, creating 100 equally-likely models each calculated with a different subset of training data. These models were then used to calculate probabilities for the testing data subsets, whereby the Hosmer-Lemeshow goodness-of-fit test at the 95\%-confidence level was applied to assess the accuracy of the model, i.e. whether the model is consistent with the testing data that were not used to calibrate it (Hosmer et al., 2013). Models that failed the Hosmer-Lemeshow test $(p<0.05)$ were discarded. High $p$-values in this test indicate a better fit as the null hypothesis states that the model fits the data. Of the remaining ensemble members, a weighted mean of the model coefficients $\left(\beta_{1 \ldots k}\right)$ was calculated to generate a final ensemble model for each of the three threshold concentrations. Weighting was applied according to the frequency that a predictor variable was retained by stepwise selection in the ensemble members. In this way, predictor variables that occurred frequently in many ensemble members received a higher weighting and greater relative importance in the final ensemble model than variables that were retained in relatively few ensemble members. Variables that were present in less than 5 out of a maximum of 100 ensemble members were not considered for the final model. See Fig. 3 for a summary of the above-mentioned procedure. A Receiver Operating Characteristics 
how well the model discriminates between low and high risk observations (Fawcett, 2006). For this, the rate of true positives (sensitivity) was plotted against the rate of true negatives (specificity) and the area under the curve (AUC) computed. An AUC value of 0.5 denotes a model that is no better than a random model, and a value of 1 would be a perfect prediction.

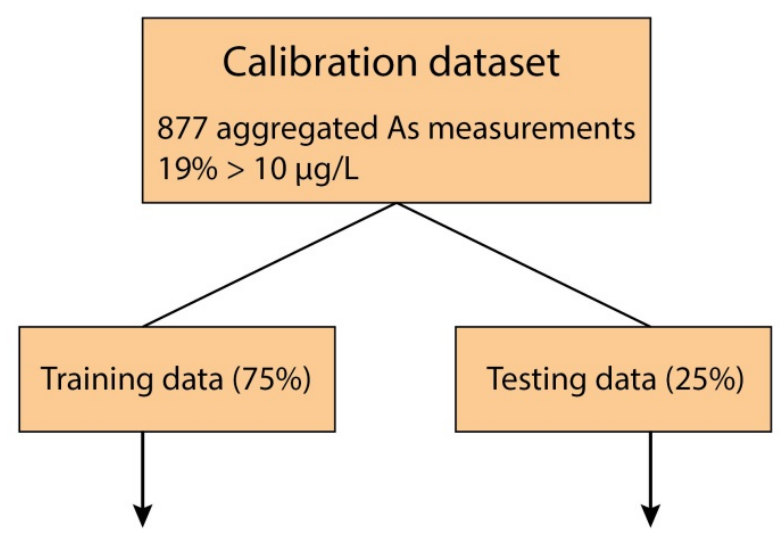

Logistic regression

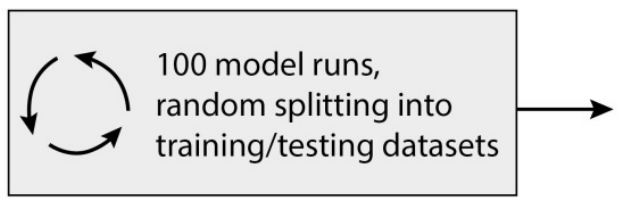

\section{Validation dataset}

314 individual As measurements $14 \%>10 \mu \mathrm{g} / \mathrm{L}$
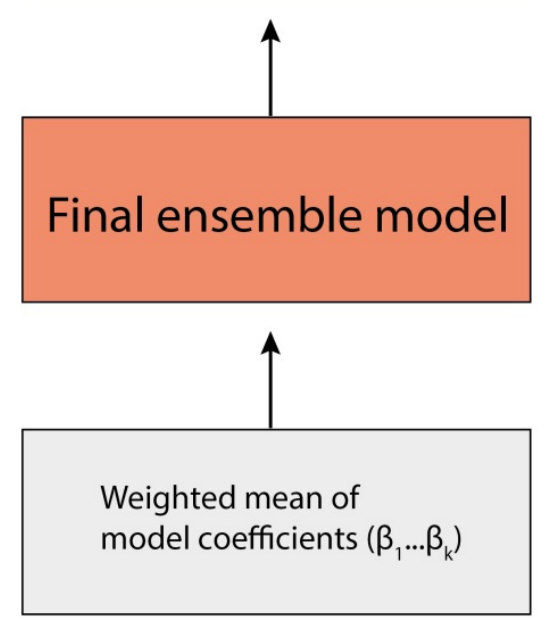

Fig. 3: Overview of the logistic regression modelling procedure

\subsection{Hazard map generation}

The final model coefficients were used to generate hazard maps showing the modelled probability of groundwater arsenic concentrations exceeding the threshold concentrations of 5, 10 and $50 \mu \mathrm{g} / \mathrm{L}$. The cut-off value to distinguish between low- and high-risk areas was chosen where the sensitivity and specificity of the model were equal (Rodríguez-Lado et al., 2013; Winkel et al., 2008). To calculate how many people are potentially affected by elevated arsenic in their drinking water, we combined the hazard map with population density estimates obtained from the Center for International Earth Science Information Network - CIESIN - Columbia University (2016). 


\subsection{Arsenic concentration data}

319 The full chemical analysis performed on the 269 new groundwater samples presented in this study

320 will only be discussed briefly here to give a broad overview of water chemistry. Results are

321 summarised in Table 4 and show that groundwater is generally near-neutral in $\mathrm{pH}$, contains dissolved

322 oxygen and is largely of good chemical quality for drinking.

323 Table 4: Summary results of field and laboratory analyses performed on new groundwater samples

\begin{tabular}{|c|c|c|c|c|c|c|c|c|c|}
\hline Parameter & Unit & Minimum & Maximum & Mean & Median & St.Dev & $n$ & $\begin{array}{c}\text { WHO } \\
\text { guideline }\end{array}$ & $\%>$ guideline \\
\hline $\mathrm{pH}$ & - & 4.85 & 8.18 & 6.75 & 6.86 & 0.45 & 221 & - & - \\
\hline EC & $\mu \mathrm{S} / \mathrm{cm}$ & 26.0 & 2311 & 369 & 339 & 219 & 220 & - & - \\
\hline $\mathrm{O}_{2}$ & $\mathrm{mg} / \mathrm{L}$ & 0.40 & 6.26 & 2.22 & 2.01 & 1.13 & 134 & - & - \\
\hline Temp & ${ }^{\circ} \mathrm{C}$ & 26.7 & 33.0 & 30.9 & 31.0 & 0.98 & 221 & - & - \\
\hline Eh & $\mathrm{mV}$ & 69 & 305 & 250 & 281 & 64 & 21 & - & - \\
\hline DOC & $\mathrm{mg} / \mathrm{L}$ & 0.25 & 3.1 & 0.42 & 0.25 & 0.48 & 269 & - & - \\
\hline TIC & $\mathrm{mgC} / \mathrm{L}$ & 1.5 & 112 & 42 & 39 & 22 & 269 & - & - \\
\hline $\mathrm{HCO}_{3}$ & $\mathrm{mg} / \mathrm{L}$ & 7.5 & 560 & 212 & 197 & 110 & 269 & - & - \\
\hline $\mathbf{F}$ & $\mathrm{mg} / \mathrm{L}$ & $<0.1$ & 2.55 & 0.28 & 0.19 & 0.36 & 269 & 1.5 & 2.6 \\
\hline $\mathrm{Cl}$ & $\mathrm{mg} / \mathrm{L}$ & $<0.1$ & 129 & 4.11 & 1.23 & 10.8 & 269 & - & - \\
\hline $\mathrm{Br}$ & $\mathrm{mg} / \mathrm{L}$ & $<0.1$ & 0.63 & 0.07 & 0.05 & 0.06 & 269 & - & - \\
\hline $\mathrm{NO}_{3}$ & $\mathrm{mg} / \mathrm{L}$ & $<0.1$ & 1060 & 17.8 & 4.6 & 69.7 & 269 & 50 & 5.6 \\
\hline $\mathrm{SO}_{4}$ & $\mathrm{mg} / \mathrm{L}$ & $<0.1$ & 1250 & 9.90 & 0.83 & 80.9 & 244 & - & - \\
\hline $\mathrm{PO}_{4}$ & $\mathrm{mg} / \mathrm{L}$ & $<0.1$ & 14.8 & 0.18 & 0.05 & 0.99 & 244 & - & - \\
\hline $\mathbf{L i}$ & $\mu \mathrm{g} / \mathrm{L}$ & $<0.1$ & 94.2 & 15.9 & 11.9 & 15.0 & 269 & - & - \\
\hline B & $\mu \mathrm{g} / \mathrm{L}$ & $<5$ & 332 & 13.0 & 5.6 & 31.5 & 269 & 2400 & - \\
\hline $\mathrm{Na}$ & $\mathrm{mg} / \mathrm{L}$ & 0.7 & 172 & 21.6 & 18.2 & 16.4 & 269 & - & - \\
\hline Mg & $\mathrm{mg} / \mathrm{L}$ & 0.2 & 110 & 14.9 & 13 & 11.8 & 269 & - & - \\
\hline Al & $\mu \mathrm{g} / \mathrm{L}$ & $<0.1$ & 1952 & 13.1 & 1.5 & 119 & 269 & $900(\mathrm{HB})$ & 0.3 \\
\hline Si & $\mathrm{mg} / \mathrm{L}$ & 5.2 & 53.3 & 26.7 & 25.5 & 10.4 & 269 & - & - \\
\hline K & $\mathrm{mg} / \mathrm{L}$ & 0.16 & 45.0 & 2.41 & 1.51 & 3.75 & 269 & - & - \\
\hline $\mathrm{Ca}$ & $\mathrm{mg} / \mathrm{L}$ & 0.6 & 318 & 30.8 & 27.3 & 30.2 & 269 & - & - \\
\hline $\mathbf{v}$ & $\mu \mathrm{g} / \mathrm{L}$ & $<0.02$ & 67.5 & 9.63 & 6.78 & 10.6 & 269 & - & - \\
\hline $\mathrm{Cr}$ & $\mu \mathrm{g} / \mathrm{L}$ & $<0.02$ & 13.6 & 0.54 & 0.15 & 1.25 & 269 & 50 & 0 \\
\hline$M n$ & $\mu \mathrm{g} / \mathrm{L}$ & $<0.02$ & 1101 & 26.8 & 4.77 & 83.9 & 269 & $400(\mathrm{HB})$ & - \\
\hline $\mathrm{Fe}$ & $\mu \mathrm{g} / \mathrm{L}$ & $<0.3$ & 6043 & 155 & 7.35 & 548 & 269 & - & - \\
\hline Co & $\mu \mathrm{g} / \mathrm{L}$ & $<0.02$ & 4.71 & 0.19 & 0.04 & 0.50 & 269 & - & - \\
\hline $\mathrm{Ni}$ & $\mu \mathrm{g} / \mathrm{L}$ & $<0.02$ & 9.51 & 0.74 & 0.38 & 0.99 & 269 & 70 & 0 \\
\hline $\mathrm{Cu}$ & $\mu \mathrm{g} / \mathrm{L}$ & $<0.1$ & 31.7 & 1.77 & 0.66 & 3.37 & 269 & 2000 & 0 \\
\hline $\mathrm{Zn}$ & $\mu \mathrm{g} / \mathrm{L}$ & $<0.1$ & 3187 & 62.0 & 7.85 & 247 & 269 & - & - \\
\hline As & $\mu \mathrm{g} / \mathrm{L}$ & $<0.02$ & 421 & 7.56 & 0.4 & 38.8 & 269 & 10 & 9.6 \\
\hline Se & $\mu \mathrm{g} / \mathrm{L}$ & $<0.02$ & 4.32 & 0.32 & 0.09 & 0.64 & 269 & 40 & 0 \\
\hline $\mathrm{Sr}$ & $\mu \mathrm{g} / \mathrm{L}$ & 8 & 3048 & 259 & 182 & 312 & 269 & - & - \\
\hline Mo & $\mu \mathrm{g} / \mathrm{L}$ & $<0.02$ & 144 & 3.53 & 0.86 & 14.3 & 269 & $70(\mathrm{HB})$ & 1.1 \\
\hline $\mathrm{Cd}$ & $\mu \mathrm{g} / \mathrm{L}$ & $<0.01$ & 3.94 & 0.04 & 0.005 & 0.25 & 269 & 3 & 0.3 \\
\hline $\mathrm{Sb}$ & $\mu \mathrm{g} / \mathrm{L}$ & $<0.01$ & 16.7 & 0.20 & 0.05 & 1.02 & 269 & 20 & 0 \\
\hline
\end{tabular}




\begin{tabular}{|llllllllll|}
$\mathrm{Ba}$ & $\mu \mathrm{g} / \mathrm{L}$ & $<0.1$ & 539 & 53.6 & 15.3 & 81.4 & 269 & 700 & 0 \\
$\mathrm{La}$ & $\mu \mathrm{g} / \mathrm{L}$ & $<0.01$ & 0.59 & 0.04 & 0.01 & 0.08 & 269 & - & - \\
$\mathrm{Ce}$ & $\mu \mathrm{g} / \mathrm{L}$ & $<0.01$ & 1.06 & 0.06 & 0.014 & 0.15 & 269 & - & - \\
$\mathbf{W}$ & $\mu \mathrm{g} / \mathrm{L}$ & $<0.02$ & 9.97 & 0.31 & 0.075 & 0.84 & 269 & - & - \\
$\mathrm{Tl}$ & $\mu \mathrm{g} / \mathrm{L}$ & $<0.02$ & 0.37 & 0.02 & 0.01 & 0.03 & 269 & - & - \\
$\mathrm{Pb}$ & $\mu \mathrm{g} / \mathrm{L}$ & $<0.02$ & 8.28 & 0.25 & 0.06 & 0.72 & 269 & 10 & 0 \\
$\mathrm{Th}$ & $\mu \mathrm{g} / \mathrm{L}$ & $<0.01$ & $<0.01$ & $<0.01$ & $<0.01$ & 0.00 & 269 & - & - \\
$\mathbf{U}$ & $\mu \mathrm{g} / \mathrm{L}$ & $<0.02$ & 8.96 & 0.21 & 0.01 & 0.90 & 269 & 30 & 0 \\
\hline
\end{tabular}

HB: health-based value, no formal guideline value established

Arsenic is by far the contaminant of greatest concern, with $9.6 \%$ of samples above the WHO and national guideline value of $10 \mu \mathrm{g} / \mathrm{L}$. Arsenic speciation measurements were carried out on few samples $(n=31)$ from the province of Balé, about $180 \mathrm{~km}$ south-west of Ouagadougou and show that arsenic is predominantly present as $\mathrm{As}(\mathrm{V})$, confirming the findings of Smedley et al. (2007).No other trace elements show significantly high concentrations and dissolved iron concentrations are typically very low. Nitrate concentrations are high in some boreholes, with $5.6 \%$ of samples above the WHO guideline value of $50 \mathrm{mg} / \mathrm{L}$ (Table 4). Drinking water boreholes are generally located in the immediate vicinity of human dwellings and are also used for watering livestock, therefore human and animal wastes are a likely source of nitrate to groundwater (Huneau et al., 2011; Nikiema et al., 2010). Geogenic fluoride contamination is restricted to the southern province of Nahouri close to the village of Tiébélé, where the fluoride concentrations of only a few samples were slightly above the WHO guideline value of $1.5 \mathrm{mg} / \mathrm{L}$ (Table 4). This region is directly adjacent to Bongo district of northern Ghana, where geogenic fluoride contamination originating from alkaline granitic rocks has been extensively documented (Alfredo et al., 2014; Apambire et al., 1997; Salifu et al., 2012).

The complete arsenic concentration dataset of 1498 measurements demonstrates that elevated levels of arsenic in groundwater are found in numerous provinces (Fig. 1, Table 1) and are not restricted to northern Burkina Faso where most previous studies were carried out (Barro-Traoré et al., 2008; Smedley et al., 2007; Somé et al., 2012). Of all 1498 collected measurements, $14.6 \%$ contained arsenic concentrations above the national and WHO guideline value of $10 \mu \mathrm{g} / \mathrm{L}$ and $2.3 \%$ above $50 \mu \mathrm{g} / \mathrm{L}$. 84\% of elevated arsenic concentrations (those above $10 \mu \mathrm{g} / \mathrm{L}$ ) fall into the range of 10 health, are much less frequent. 
352

353

354

355

356

357

358

359

360

361

Figure 4 shows the percentage of samples above the given arsenic thresholds according to the host rock type. Although arsenic concentrations above $5 \mu \mathrm{g} / \mathrm{L}$ are found in all rock types with only a slight preference for Birimian lithologies, those above 10 and $50 \mu \mathrm{g} / \mathrm{L}$ are increasingly more likely to be only found in volcano-sedimentary schists and volcanic rocks (basalt, andesite, rhyolite) of the Birimian formation and are much less common in groundwater from granitic rocks (granite, tonalite, granodiorite). This supports findings from previous studies (e.g. Smedley et al. (2007)) that arsenic is linked to the occurrence of sulphide minerals in volcano-sedimentary rocks of the Birimian formation. Geogenic arsenic in groundwater is much less common in granitic areas, which have not undergone widespread alteration or hydrothermalisation processes leading to the formation of mineral deposits.

(A) Calibration dataset

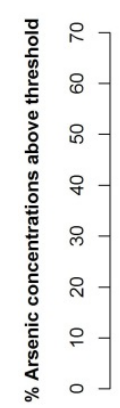

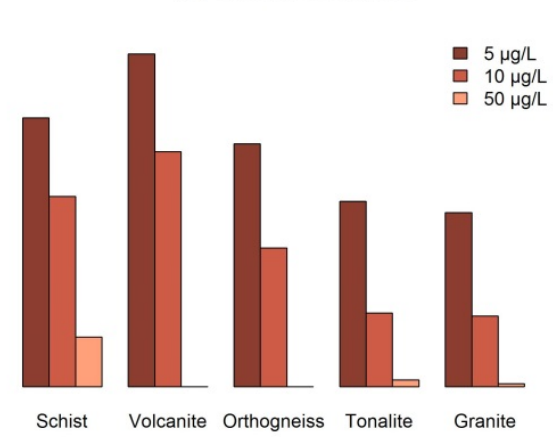

(B) Validation dataset

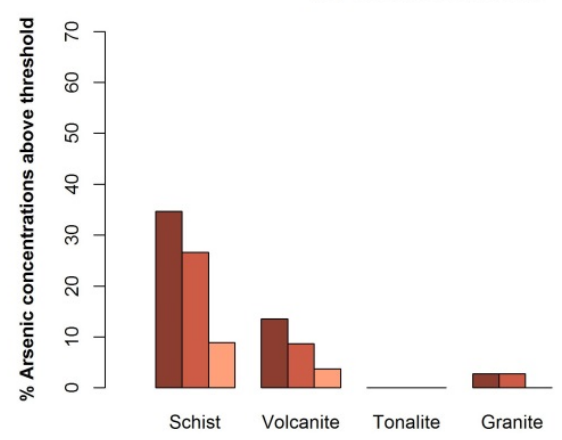

Fig. 4: Bar graphs showing the distribution of arsenic concentrations above the chosen threshold value in relation to the lithology of the aquifer. A) displays the calibration dataset (aggregated to one arsenic value per $1 \mathrm{~km}^{2}$ pixel as was used for modelling, $\mathrm{n}=877$ ), B) the validation dataset ( $\left.\mathrm{n}=314\right)$. The rock type "Orthogneiss" does not occur in areas where water was sampled for the validation dataset and is therefore not represented on the graph on the right.

Arsenopyrite and pyrite occurrence in the Birimian greenstone belts has been documented in numerous studies, e.g. Milési et al. (1992), Béziat et al. (2008). Unfortunately, data on arsenic concentrations in pyrite minerals in Burkina Faso were not available. . A database of geochemical analyses of 482 rock samples taken throughout Burkina Faso in both granitic and volcanic/metamorphic terranes (Castaing et al., 2003a) showed few samples $(n=27)$ that had arsenic concentrations greater than the upper crustal abundance of $5.7 \mathrm{mg} / \mathrm{kg}$ given in Hu and Gao (2008). All of these high-As samples were located within the Birimian greenstone belts and were volcanic, meta-volcanic or meta-sedimentary rocks, with the highest arsenic concentration of $55 \mathrm{mg} / \mathrm{kg}$ being 
measured in a meta-basalt sample. Arsenic in groundwater can be assumed to originate from sulphide minerals in such rocks, however identifying the sources of high concentrations in specific boreholes would require very local, in-depth geochemical studies with rock samples ideally being taken during borehole drilling.

Groundwater arsenic concentrations are subject to a great degree of spatial variability, with arsenicaffected wells often in direct proximity to "safe" wells. This effect is observed in nearly all arsenicaffected areas worldwide, regardless of the geological setting and arsenic mobilisation mechanism and indicates that arsenic concentration in groundwater is influenced by very local, small-scale conditions (Fendorf et al., 2010; Van Geen et al., 2003). In Burkina Faso, the occurrence of potentially arsenic-containing sulphide minerals (pyrite, arsenopyrite) is linked to gold-bearing quartz veins that are heterogeneously distributed within the volcano-sedimentary schists and volcanic rocks of the Birimian belts. The occurrence of sulphide minerals can therefore vary over a scale of meters, depending on the size of mineralised veins. Smedley et al. (2007) hypothesised that As(V) may reach high dissolved concentrations in direct proximity to these mineralised zones, where it may be in equilibrium with secondary Fe-oxides having high sorbed $A s(V)$ loads. In addition, groundwater may flow in fractures that are totally isolated from each other. It is plausible that anoxic/suboxic zones may develop in such fractures, locally favouring the desorption of $\mathrm{As}$ (III) bound to Fe-oxides as has been suggested by Yang et al. (2015). Whether a borehole intercepts a groundwater flow path very close to a mineralised zone is likely the main factor affecting whether or not elevated arsenic is present in the well.

\subsection{Predicting arsenic-affected areas}

Logistic regression was performed on the calibration dataset for the three chosen thresholds using eight explanatory variables as predictors for elevated groundwater arsenic occurrence. For all three thresholds, only some of the lithological variables were significantly related to the presence of elevated arsenic as shown by the mean model coefficients (Table 5), whereas the distance variables (faults, mineral deposits, granitic intrusions) did not have a significant influence on the final ensemble model. Volcano-sedimentary schists of the Birimian formation increase the odds of wells having elevated arsenic for all three thresholds. Birimian volcanites (basalt, andesite, rhyolite) and Birimian orthogneiss are also positive indicators for arsenic being above 5 and $10 \mu \mathrm{g} / \mathrm{L}$. The higher the arsenic concentration, the fewer variables were significant in the model, with volcanosedimentary schist being the dominant variable, causing a 4-fold and 17-fold increase in the odds of arsenic being above $10 \mu \mathrm{g} / \mathrm{L}$ respectively $50 \mu \mathrm{g} / \mathrm{L}$ (Table 5). The probability maps in Figure 5 highlight 
areas that are vulnerable to elevated groundwater arsenic, showing probabilities of arsenic 411 exceeding the specified threshold values.

413 Table 5: Weight-averaged coefficients ( $\beta$ ), standard deviation and frequency per 100 model runs of predictor 414 variables that were retained in the final ensemble models. The averaged $p$-value of the Hosmer-Lemeshow (HL) 415 goodness-of-fit test for the significant ensemble members is given in the last column (high p-values denote 416 significance).

\begin{tabular}{|c|c|c|c|c|c|}
\hline Predictor variables & Coefficient $\beta$ & $\operatorname{Exp}(\beta)$ & St. dev. & Freq. in analyses & $\begin{array}{c}\text { p-value HL } \\
\text { test }\end{array}$ \\
\hline \multicolumn{6}{|c|}{$5 \mu \mathrm{g} / \mathrm{L}$ threshold } \\
\hline Volcano-sedimentary schist (Birimian) & 0.7 & 2.01 & 0.12 & 89 & \multirow{4}{*}{0.87} \\
\hline Volcanite (Birimian) & 1.19 & 3.29 & 0.24 & 90 & \\
\hline Orthogneiss (Birimian) & 0.33 & 1.39 & 0.35 & 46 & \\
\hline Distance to granitic intrusions & 0.04 & 1.03 & 0.76 & 6 & \\
\hline \multicolumn{6}{|c|}{$10 \mu \mathrm{g} / \mathrm{L}$ threshold } \\
\hline Volcano-sedimentary schist (Birimian) & 1.3 & 3.67 & 0.11 & 98 & \multirow{3}{*}{0.91} \\
\hline Volcanite (Birimian) & 1.68 & 5.37 & 0.26 & 98 & \\
\hline Orthogneiss (Birimian) & 0.74 & 2.1 & 0.2 & 83 & \\
\hline \multicolumn{6}{|c|}{$50 \mu \mathrm{g} / \mathrm{L}$ threshold } \\
\hline Volcano-sedimentary schist (Birimian) & 2.82 & 16.77 & 0.54 & 27 & \multirow{2}{*}{0.93} \\
\hline Tonalite, granodiorite & 0.48 & 1.61 & 1.37 & 8 & \\
\hline
\end{tabular}




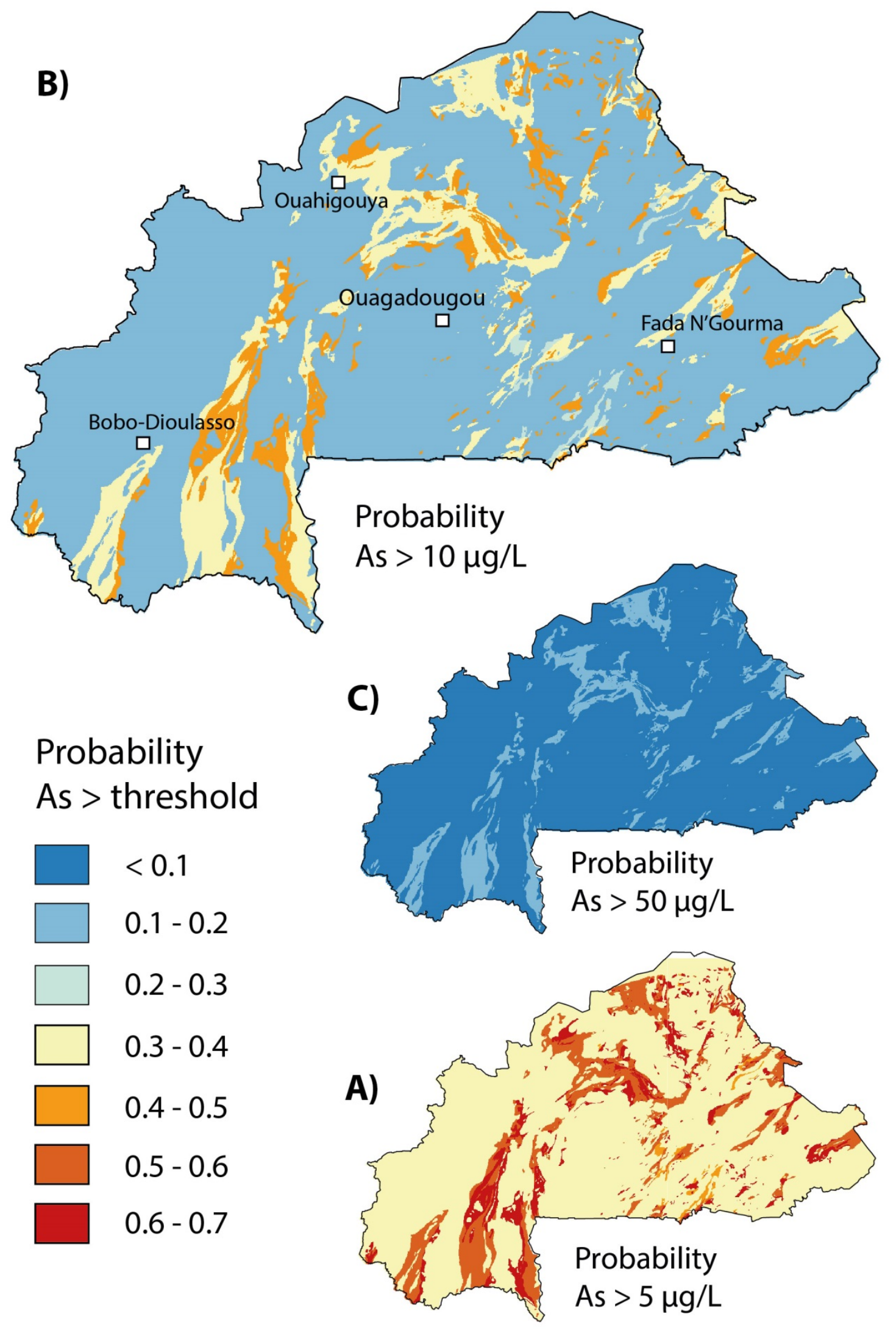

Fig. 5: Modelled probability of groundwater arsenic concentrations exceeding the threshold values of A) $5 \mu \mathrm{g} / \mathrm{L}$, B) $10 \mu g / L$ and C) $50 \mu g / L$ 
The highest probabilities (0.7) are calculated for the threshold of $5 \mu \mathrm{g} / \mathrm{L}$, meaning that there is a $70 \%$ chance of finding arsenic concentrations above $5 \mu \mathrm{g} / \mathrm{L}$ in a well in this region. The low AUC value (0.57, Fig. 6) denotes rather poor discriminating power of the model. This is not surprising for this low threshold and reflects the nature of the calibration data: water with arsenic greater than $5 \mu \mathrm{g} / \mathrm{L}$ is well-represented in all rock types used as predictor variables, with only a slight preference for lithologies of the Birimian formation (Fig. 4). The lack of a clear, distinguishing predictor variable means that the specificity and sensitivity of the model are low, as high arsenic values are frequently classified into low-risk areas and vice-versa. The AUC for the $10 \mu \mathrm{g} / \mathrm{L}$ model of 0.63 is also not very high. This also indicates that high arsenic values are often found outside the regions classified as "high risk", reflecting the heterogeneity of the calibration dataset and the inability to find a clear predictor for high arsenic. Even though arsenic concentrations $>10 \mu \mathrm{g} / \mathrm{L}$ are mainly found in volcanites and volcano-sedimentary schist, some occurrences are also found in granitic rocks (granite and tonalite) (Fig. 4), which were not determined to be significant predictors. These arsenic measurements therefore plot as high values in low-risk areas, which reduces the model's specificity. The best AUC is calculated for the threshold of $50 \mu \mathrm{g} / \mathrm{L}$, where volcano-sedimentary schists are the clearest predictor of high arsenic concentrations and the few high values are correctly classified.

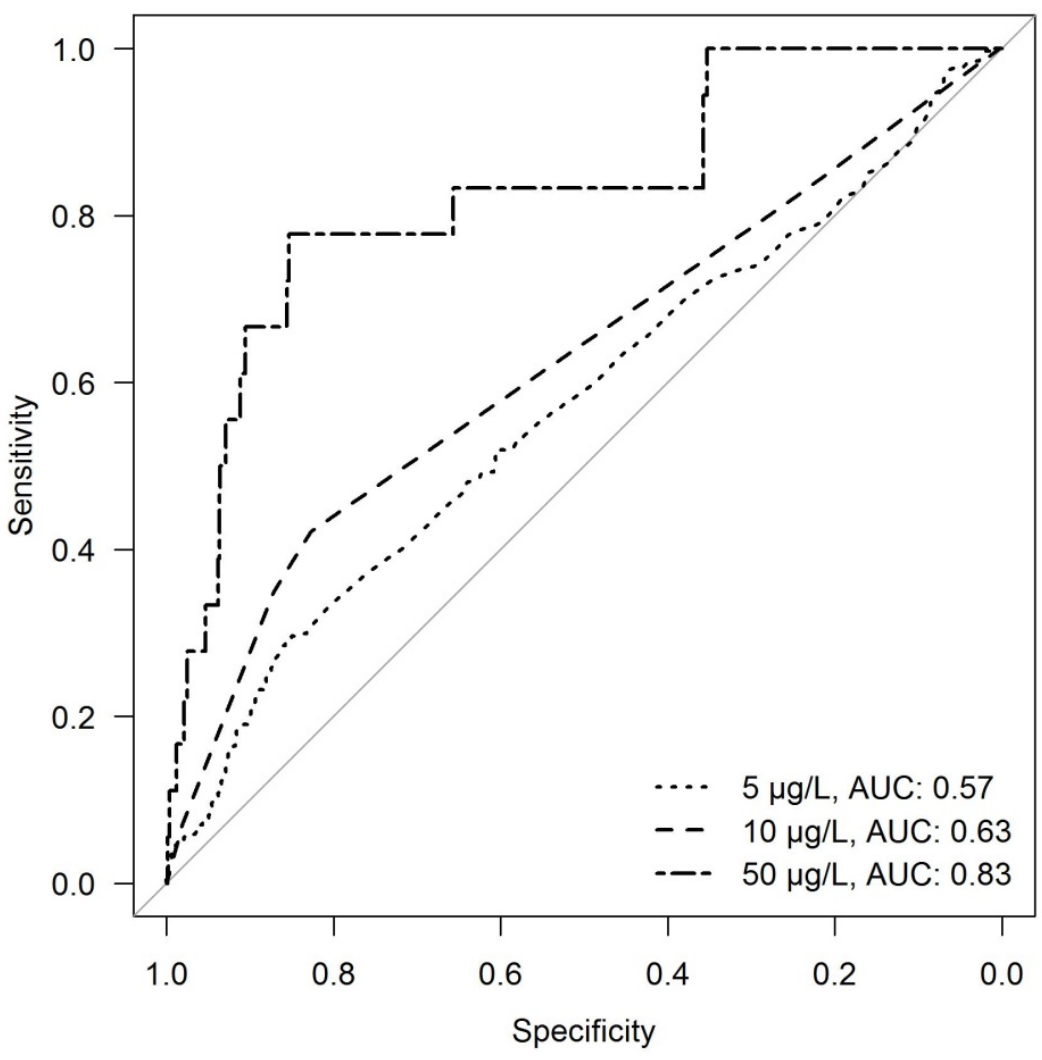
different thresholds. The area under the curve (AUC) is displayed in the legend. 
442 Even though mineral deposits are hypothesized to be excellent proxies for mineralised zones, they 443 were not a significant predictor for arsenic in the logistic regression model. This is not surprising 444 when we consider that mineralised zones exist where mineral exploration may not have taken place 445 yet or which are too limited in extent to be economical for mineral extraction. Nevertheless, such 446 areas are still potential arsenic sources and may yield elevated groundwater arsenic concentrations 447 even though they are not documented in the mineral deposits dataset. Most of the high-arsenic 448 samples in the calibration dataset are from areas more than $10 \mathrm{~km}$ from documented mineral 449 deposits. We therefore see the incompleteness of the mineral deposit dataset we used as the reason 450 for its poor performance in predicting As-affected areas, and not the unsuitability of mineralised 451 zones as As-predictors as such.

\subsection{Model validation}

455 The validation dataset, composed of 313 independent groundwater arsenic measurements was used 456 to verify the validity of the prediction model in other regions of Burkina Faso outside of the 457 geographical distribution of the calibration dataset. The validation data are located in the north, 458 south and west of the country (Fig. 1) with $14 \%$ of concentrations above $10 \mu \mathrm{g} / \mathrm{L}$. The $10 \mu \mathrm{g} / \mathrm{L}$ 459 probability map was first classified into "high risk" and "low risk" zones by taking 0.2 as the probability cut-off value. The validation data were then plotted on this map and the rate of correct classification calculated (Fig. 7). Results presented in Table 6 show that 91\% of high arsenic values (> $10 \mu \mathrm{g} / \mathrm{L}$ ) were correctly classified into high-risk areas (sensitivity, true positives), with only $9 \%$ plotting in low-risk regions (false negatives). For the low arsenic concentrations, 39\% of these were correctly classified into low-risk areas (specificity, true negatives), with the remaining $61 \%$ in high risk areas (false positives). The high rate of false positives again reflects the nature of the arsenic concentration database, with only few high-arsenic wells being scattered among a majority of arsenic-safe wells. From a drinking water quality perspective, the high rate of false positives is not worrying, as finding good water quality in a high-risk area is a positive outcome. Much more important is the good performance of the model in predicting high-risk areas, with very few higharsenic values plotting in low-risk areas. 


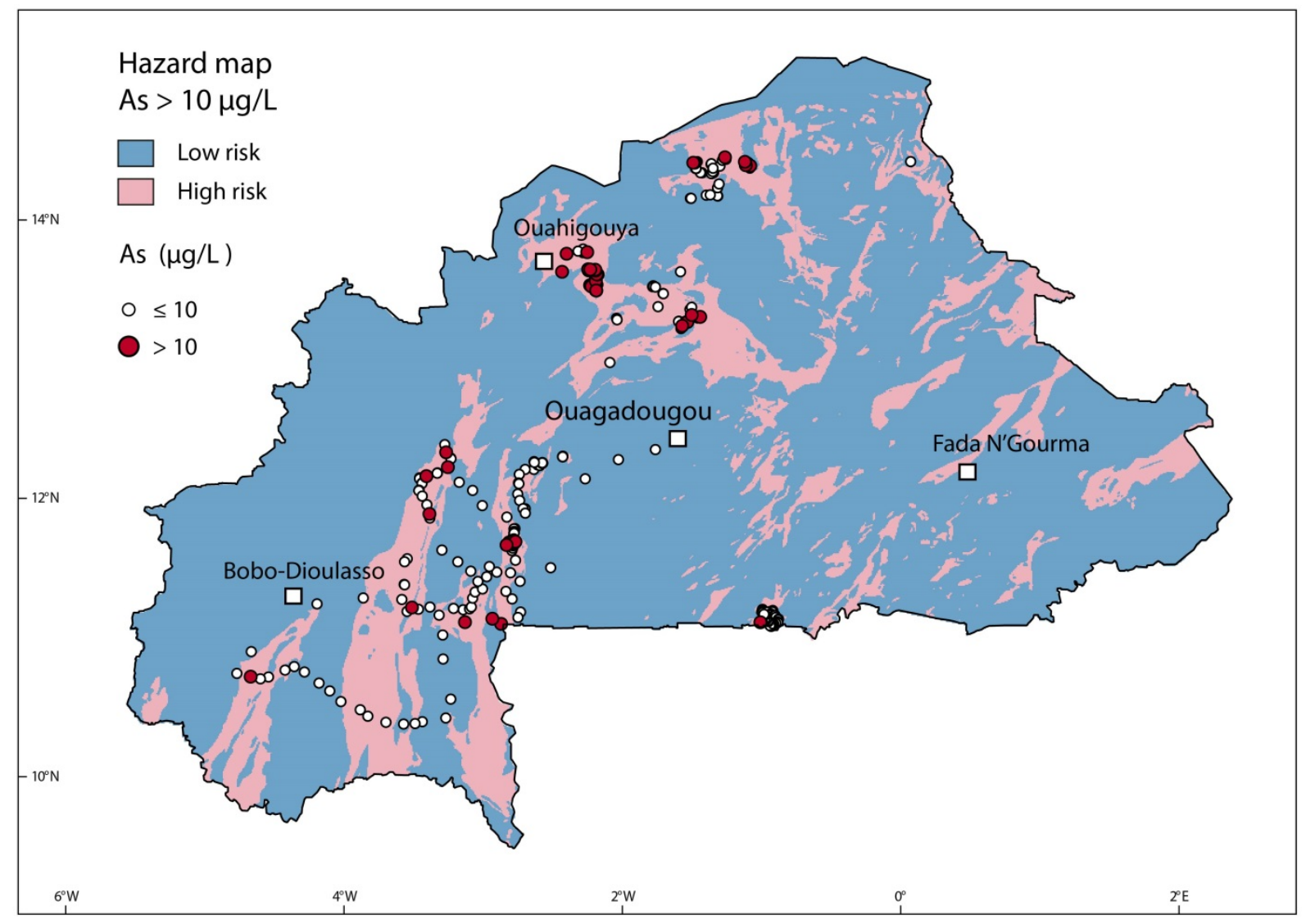

Fig. 7: Arsenic hazard map divided into "high" and "low" risk zones according to the probability cut-off of 0.2 of the $10 \mu \mathrm{g} / \mathrm{L}$ prediction model, overlain by the validation dataset of arsenic measurements ( $n=314)$.

Even though the presented hazard maps highlight areas at greater risk of arsenic contamination, they cannot accurately predict high arsenic concentrations of individual boreholes, since the spatial resolution of predictor variables is much coarser than the small-scale variability that can occur between boreholes. Such data cannot represent the extremely localised processes leading to highly varying arsenic concentrations in wells situated within hundreds of metres of each other. Ideally, to more accurately predict arsenic occurrence in Burkina Faso, one would need highly detailed maps of gold and/or sulphide mineral deposits (showing individual mineral veins) on a country-wide scale, as well as borehole logs showing the lithological structure and location of water-bearing fractures at depth. 


\begin{tabular}{|l|l|l|l|}
\hline $\begin{array}{l}\text { Validation dataset, } \\
\mathbf{n = 3 1 3}\end{array}$ & $\begin{array}{l}\text { No. of } \\
\text { samples }\end{array}$ & Predicted $>10 \mu \mathrm{g} / \mathrm{L}$ (high risk) & Predicted $\leq 10 \mu \mathrm{g} / \mathrm{L}$ (low risk) \\
\hline $\begin{array}{l}\text { Observed }>10 \mu \mathrm{g} / \mathrm{L} \\
\text { (high As) }\end{array}$ & $\mathbf{4 4}$ & 40 (91\% true positives) & 4 (9\% false negatives) \\
\hline $\begin{array}{l}\text { Observed } \leq 10 \mu \mathrm{g} / \mathrm{L} \\
\text { (low As) }\end{array}$ & $\mathbf{2 6 9}$ & $165(61 \%$ false positives) & 104 (39\% true negatives) \\
\hline
\end{tabular}

\subsection{Population at risk}

Using large scale and readily available geological data and a detailed dataset of arsenic measurements, we have produced a statistically sound hazard map predicting areas that are more likely to contain high concentrations of geogenic groundwater arsenic in Burkina Faso. By combining predicted high-risk areas (> $20 \%$ chance of finding high arsenic concentrations) with population density, the total population at risk of drinking water elevated in arsenic (>10 $\mu \mathrm{g} / \mathrm{L}$ ) were estimated (Fig. 8). Burkina Faso sustains a largely rural population, with only $30 \%$ living in urban areas (UNICEF and World Health Organization, 2015). Altogether, about 4 million people, which is roughly one-fifth of the total population of 17.3 million, live in designated high-risk areas. Considering the calculated statistical probability that about 1 in 5 boreholes in these high-risk regions are contaminated with arsenic, about 560,000 people are potentially exposed to contaminated groundwater. Since groundwater is the main source of drinking water in rural areas and arsenic treatment techniques are as yet very rarely implemented, we consider this figure to be a valid estimate. This is a daunting number for one of the poorest and least-developed countries that is already facing numerous issues concerning water and sanitation (UNDP, 2015; UNICEF and World Health Organization, 2015). Even though large-scale targeted medical studies have not been undertaken to the authors' knowledge, arsenic-related health issues can be expected to be widespread and result in a considerable burden of disease and reduced productivity and life expectancy in the Burkinabè population. In addition, socio-economic, demographic and political conditions will contribute considerably to a population's total vulnerability to arsenic exposure (Singh \& Vedwan, 2015). 


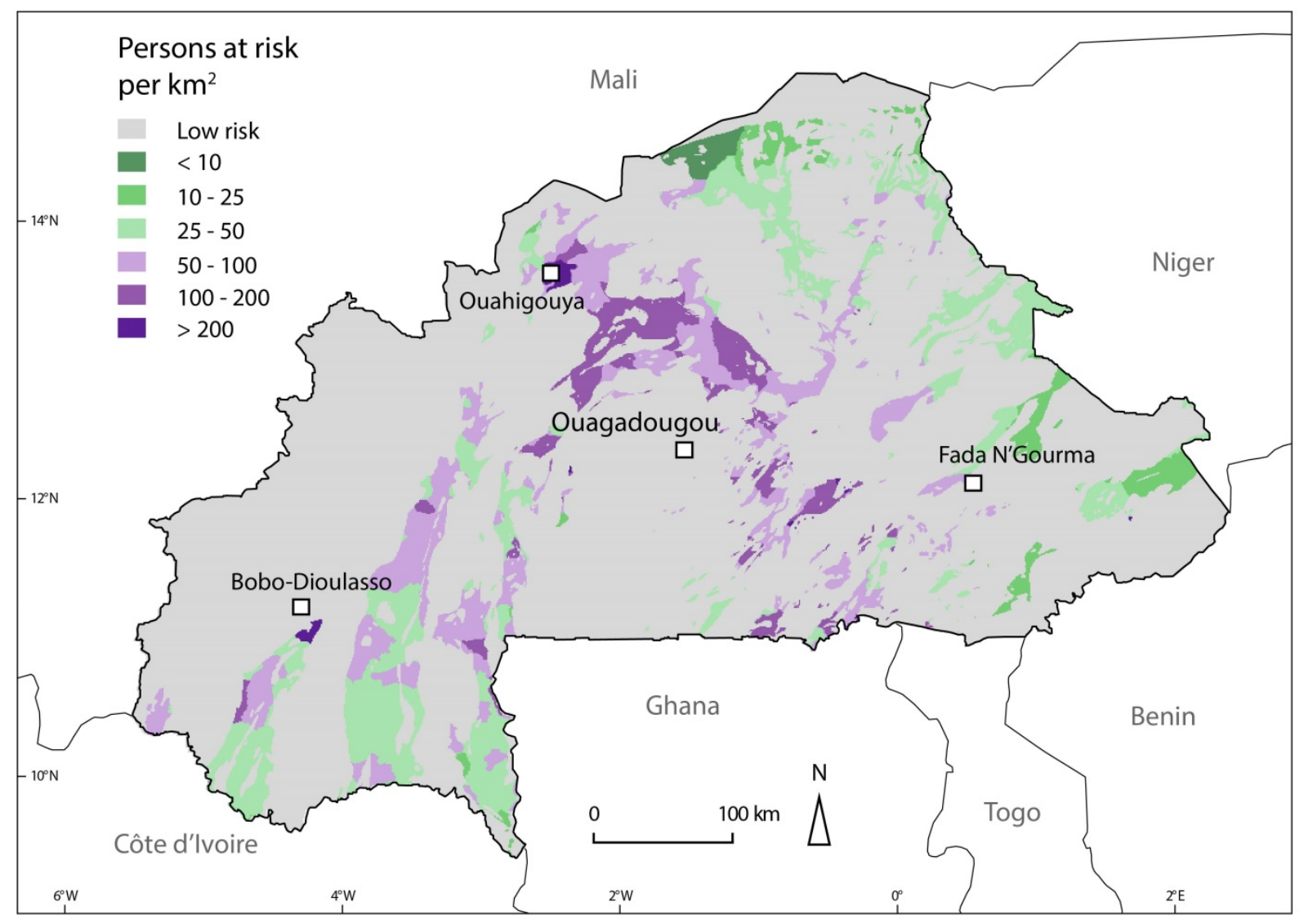

Fig. 8: Estimated number of persons at risk of being exposed to groundwater arsenic concentrations $>10 \mu \mathrm{g} / \mathrm{L}$ per $\mathrm{km}^{2}$ in Burkina Faso. Population density data from the Center for International Earth Science Information Network - CIESIN - Columbia University (2016)

\subsection{Relevance for arsenic mitigation in Burkina Faso and the greater West African region}

The presented arsenic hazard maps are aimed as a tool for water resource authorities to conduct drinking water surveys in areas where they are most needed. The testing of each drinking water well in high-risk regions is still necessary, as relatively few high-arsenic wells are generally distributed among many low-arsenic wells. The current practice is to close arsenic-affected wells with a chain or to dismantle them to prevent water abstraction by the population. Often a replacement well is not drilled in the vicinity, leading to water shortages and greatly increased walking distances and hardship for women and children in charge of water collection. Closing a well without replacement only makes sense if an alternative, arsenic-free well is nearby, which may certainly be the case since several drinking water boreholes are often installed in a village.

Well-switching has proved to be a popular mitigation option in arsenic-affected regions in

527 Bangladesh and is preferred over technological solutions such as water treatment filters (Ahmed et al., 2006; Inauen et al., 2013). Only where alternative, arsenic-safe wells are too far away does on- 
site arsenic treatment or the drilling of a new well make sense. Some success and encouraging results have already been seen in Burkina Faso with the installation of community-scale arsenic treatment filters by $2 \mathrm{iE}-$ Fondation based on commercially available iron-hydroxide filter materials, though this is not yet widespread (Ouedraogo, 2016). The installation of a filter needs careful operation and maintenance, trained local staff, frequent water quality monitoring, replacement of filter material when saturated, and, above all, the necessary funding for sustainable, long-term operation. These can be daunting tasks for remote rural communities and need to be addressed before any upscaling of filter techniques is possible. Therefore, switching to alternative, arsenic-free wells, where possible, is definitely the preferred mitigation option in Burkina Faso at the moment.

The arsenic hazard model generated may also be relevant in Burkina Faso's neighbouring countries, as the volcanites and volcano-sedimentary schists of the Birimian formation, which proved to be the most reliable predictor for high arsenic, also cover large areas of Ghana, the Ivory Coast, Mali, Niger and Benin. A transboundary hazard map for the whole West African region, calibrated and validated with local data would be a first step in creating awareness of geogenic arsenic contamination on a more regional scale and initiating necessary mitigation in affected areas.

\section{Acknowledgements}

The authors would like to thank Marcelle Ahissan, Lucien Stolze and Désiré Boro for assistance during field work in Burkina Faso. Thanks also goes to the NGOs "Le soleil dans la main" and "Fastenopfer" for taking water samples that complemented the arsenic concentration dataset, and to Pauline Smedley for permission to use arsenic data from her 2007 study. We acknowledge the laboratory staff at 2iE for storage of equipment and samples. Many thanks to Stephan Hug for useful comments that improved this manuscript and to Christian Zurbrügg for his helpful advice and diplomacy during the course of the project. Funding for this study was provided through the "Programme 3E" of the Swiss Agency for Development and Cooperation (SDC).

\section{References}

Abraitis, P. K., Pattrick, R. A. D., \& Vaughan, D. J. (2004). Variations in the compositional, textural and electrical properties of natural pyrite: A review. International Journal of Mineral Processing, 74(1-4), 41-59.

Ahmed, K. M., Bhattacharya, P., Hasan, M. A., Akhter, S. H., Alam, S. M. M., Bhuyian, M. A. H., Imam, M. B., Khan, A. A., \& Sracek, O. (2004). Arsenic enrichment in groundwater of the alluvial aquifers in Bangladesh: An overview. Applied Geochemistry, 19(2), 181-200. 
Ahmed, M. F., Ahuja, S., Alauddin, M., Hug, S. J., Lloyd, J. R., Pfaff, A., Pichler, T., Saltikov, C., Stute, M., \& Van Geen, A. (2006). Ensuring safe drinking water in Bangladesh. Science, 314(5806), 1687-1688. doi: 10.1126/science.1133146

Ahn, J. S., \& Cho, Y. C. (2013). Predicting natural arsenic contamination of bedrock groundwater for a local region in Korea and its application. Environmental Earth Sciences, 68(7), 2123-2132.

Ahoulé, D., Lalanne, F., Mendret, J., Brosillon, S., \& Maïga, A. (2015). Arsenic in African Waters: A Review. Water, Air, \& Soil Pollution, 226(9), 1-13. doi: 10.1007/s11270-015-2558-4

Akaike, H. (1974). A New Look at the Statistical Model Identification. IEEE Transactions on Automatic Control, 19(6), 716-723. doi: 10.1109/TAC.1974.1100705

Alfredo, K. A., Lawler, D. F., \& Katz, L. E. (2014). Fluoride contamination in the Bongo District of Ghana, West Africa: Geogenic contamination and cultural complexities. Water International, 39(4), 486-503. doi: 10.1080/02508060.2014.926234

Amini, M., Abbaspour, K. C., Berg, M., Winkel, L., Hug, S. J., Hoehn, E., Yang, H., \& Johnson, C. A. (2008). Statistical modeling of global geogenic arsenic contamination in groundwater. Environmental Science and Technology, 42(10), 3669-3675.

Apambire, W. B., Boyle, D. R., \& Michel, F. A. (1997). Geochemistry, genesis, and health implications of fluoriferous groundwaters in the upper regions of Ghana. Environmental Geology, 33(1), 13-24.

Argos, M., Kalra, T., Rathouz, P. J., Chen, Y., Pierce, B., Parvez, F., Islam, T., Ahmed, A., RakibuzZaman, M., Hasan, R., Sarwar, G., Slavkovich, V., Van Geen, A., Graziano, J., \& Ahsan, H. (2010). Arsenic exposure from drinking water, and all-cause and chronic-disease mortalities in Bangladesh (HEALS): A prospective cohort study. The Lancet, 376(9737), 252-258.

Asante, K. A., Agusa, T., Subramanian, A., Ansa-Asare, O. D., Biney, C. A., \& Tanabe, S. (2007). Contamination status of arsenic and other trace elements in drinking water and residents from Tarkwa, a historic mining township in Ghana. Chemosphere, 66(8), 1513-1522.

Ayotte, J. D., Nolan, B. T., \& Gronberg, J. A. (2016). Predicting Arsenic in Drinking Water Wells of the Central Valley, California. Environmental Science and Technology, 50(14), 7555-7563. doi: 10.1021/acs.est.6b01914

Ayotte, J. D., Nolan, B. T., Nuckols, J. R., Cantor, K. P., Robinson Jr, G. R., Baris, D., Hayes, L., Karagas, M., Bress, W., Silverman, D. T., \& Lubin, J. H. (2006). Modeling the probability of arsenic in groundwater in New England as a tool for exposure assessment. Environmental Science and Technology, 40(11), 3578-3585.

Barro-Traoré, F., Tiendrébéogo, S. R. M., Lallogo, S., Tiendrébéogo, S., Dabal, M., \& Ouédraogo, H. (2008). Manifestations cutanées de l'arcénicisme au Burkina Faso: aspects épidémiologiques et cliniques. Mali Medical, tome XXIII(1).

Berg, M., Stengel, C., Trang, P. T. K., Hung Viet, P., Sampson, M. L., Leng, M., Samreth, S., \& Fredericks, D. (2007). Magnitude of arsenic pollution in the Mekong and Red River Deltas Cambodia and Vietnam. Science of the Total Environment, 372(2-3), 413-425.

Berg, M., Trang, P. T. K., Stengel, C., Buschmann, J., Viet, P. H., Van Dan, N., Giger, W., \& Stüben, D. (2008). Hydrological and sedimentary controls leading to arsenic contamination of groundwater in the Hanoi area, Vietnam: The impact of iron-arsenic ratios, peat, river bank deposits, and excessive groundwater abstraction. Chemical Geology, 249(1-2), 91-112. doi: 10.1016/j.chemgeo.2007.12.007

Béziat, D., Dubois, M., Debat, P., Nikiéma, S., Salvi, S., \& Tollon, F. (2008). Gold metallogeny in the Birimian craton of Burkina Faso (West Africa). Journal of African Earth Sciences, 50(2-4), 215 233.

Bhattacharya, P., Chatterjee, D., \& Jacks, G. (1997). Occurrence of arsenic-contaminated groundwater in alluvial aquifers from delta plains, eastern India: options for safe drinking water supply. Water Resources Development, 13(1), 79-92. doi: 10.1080/07900629749944

Bourges, F., Debat, P., Tollon, F., Munoz, M., \& Ingles, J. (1998). The geology of the Taparko gold deposit, Birimian greenstone belt, Burkina Faso, West Africa. Mineralium Deposita, 33(6), 591-605. doi: DOI 10.1007/s001260050175 
Buamah, R., Petrusevski, B., \& Schippers, J. C. (2008). Presence of arsenic, iron and manganese in groundwater within the gold-belt zone of Ghana. Journal of Water Supply: Research and Technology - AQUA, 57(7), 519-529.

Buschmann, J., Berg, M., Stengel, C., \& Sampson, M. L. (2007). Arsenic and manganese contamination of drinking water resources in Cambodia: Coincidence of risk areas with low relief topography. Environmental Science and Technology, 41(7), 2146-2152.

Castaing, C., Billa, M., Milesi, J. P., Thieblemont, D., Le Metour, J., Egal, E., Donzeau, M., Buerrot, C., Cocherie, A., Chevremont, P., Tegyey, M., Itard, Y., Zida, B., Ouedraogo, I., Kote, S., Kabore, B. E., Ouedraogo, C., Ki, J. C., \& Zunino, C. (2003a). Notice explicative de la Carte géologique et minière du Burkina Faso à 1/1 000 000. Ouagadougou, Burkina Faso.

Castaing, C., Le Metour, J., Billa, M., Donzeau, M., Chevremont, P., Egal, E., Zida, B., Ouedraogo, I., Kote, S., Kabore, B. E., Ouedraogo, C., Thieblemont, D., Guerrot, C., Cocherie, A., Tegyey, M., Milesi, J. P., \& Itard, Y. (2003b). Carte géologique et minière du Burkina Faso à 1/1 000000. Ouagadougou, Burkina Faso.

Center for International Earth Science Information Network - CIESIN - Columbia University. (2016). Gridded Population of the World, Version 4 (GPWv4): Population Density. Retrieved from: http://dx.doi.org/10.7927/H4NP22DQ

Courtois, N., Lachassagne, P., Wyns, R., Blanchin, R., Bougaïré, F. D., Somé, S., \& Tapsoba, A. (2010). Large-scale mapping of hard-rock aquifer properties applied to Burkina Faso. Ground Water, 48(2), 269-283.

COWI. (2004). Etude sur I'arsenic dans l'eau souterraine de la zone du PEEN COWI Engineering, Programme Eau et Environnement - Région du Nord : Ministère de l'Agriculture, de I'Hydraulique et des Ressources Halieutiques - Burkina Faso. Copenhagen.

Dewandel, B., Maréchal, J. C., Bour, O., Ladouche, B., Ahmed, S., Chandra, S., \& Pauwels, H. (2012). Upscaling and regionalizing hydraulic conductivity and effective porosity at watershed scale in deeply weathered crystalline aquifers. Journal of Hydrology, 416-417, 83-97. doi: 10.1016/j.jhydrol.2011.11.038

Dixit, S., \& Hering, J. G. (2003). Comparison of arsenic(V) and arsenic(III) sorption onto iron oxide minerals: Implications for arsenic mobility. Environmental Science and Technology, 37(18), 4182-4189.

Dummer, T. J. B., Yu, Z. M., Nauta, L., Murimboh, J. D., \& Parker, L. (2015). Geostatistical modelling of arsenic in drinking water wells and related toenail arsenic concentrations across Nova Scotia, Canada. Science of the Total Environment, 505, 1248-1258. doi: 10.1016/j.scitotenv.2014.02.055

Edmunds, W. M. (2008). Groundwater in Africa - palaeowater, climate change and modern recharge. In S. Adelana \& A. MacDonald (Eds.), Applied Groundwater Studies in Africa: Taylor \& Francis.

Fawcett, T. (2006). An introduction to ROC analysis. Pattern Recognition Letters, 27(8), 861-874. doi: DOI 10.1016/j.patrec.2005.10.010

Fendorf, S., Michael, H. A., \& Van Geen, A. (2010). Spatial and temporal variations of groundwater arsenic in South and Southeast Asia. Science, 328(5982), 1123-1127.

Filippi, C., Milville, F., \& Thiery, D. (1990). Evaluation of natural recharge to aquifers in the sudansahel climate using global hydrological modelling: Application to ten sites in burkina faso. Hydrological Sciences Journal, 35(1), 29-48. doi: 10.1080/02626669009492403

Flanagan, S. V., Johnston, R. B., \& Zheng, Y. (2012). Arsenic in tube well water in Bangladesh: health and economic impacts and implications for arsenic mitigation. Bulletin of the World Health Organization, 90(11), 839-846. doi: 10.2471/blt.11.101253

GRASS Development Team. (2015). Geographic Resources Analysis Support System (GRASS) Software, Version 7.0: Open Source Geospatial Foundation. Retrieved from http://grass.osgeo.org

Hosmer, D. W., Lemeshow, S., \& Sturdivant, R. X. (2013). Applied logistic regression (Vol. 398): John Wiley \& Sons.

Hu, Z., \& Gao, S. (2008). Upper crustal abundances of trace elements: A revision and update. Chemical Geology, 253(3-4), 205-221. doi: http://dx.doi.org/10.1016/j.chemgeo.2008.05.010 
Hug, S. J., \& Leupin, O. (2003). Iron-catalyzed oxidation of Arsenic(III) by oxygen and by hydrogen peroxide: $\mathrm{pH}$-dependent formation of oxidants in the Fenton reaction. Environmental Science and Technology, 37(12), 2734-2742. doi: 10.1021/es026208x

Huneau, F., Dakoure, D., Celle-Jeanton, H., Vitvar, T., Ito, M., Traore, S., Compaore, N. F., Jirakova, H., \& Le Coustumer, P. (2011). Flow pattern and residence time of groundwater within the south-eastern Taoudeni sedimentary basin (Burkina Faso, Mali). Journal of Hydrology, 409(12), 423-439.

Inauen, J., Hossain, M. M., Johnston, R. B., \& Mosler, H. J. (2013). Acceptance and Use of Eight Arsenic-Safe Drinking Water Options in Bangladesh. PLOS ONE, 8(1). doi: 10.1371/journal.pone.0053640

Lehner, B., Verdin, K., \& Jarvis, A. (2008). New global hydrography derived from spaceborne elevation data. Eos, 89(10), 93-94.

MacDonald, A. M., \& Calow, R. C. (2009). Developing groundwater for secure rural water supplies in Africa. Desalination, 248(1-3), 546-556. doi: 10.1016/j.desal.2008.05.100

MacDonald, A. M., Calow, R. C., MacDonald, D. M. J., Darling, W. G., \& Dochartaigh, B. E. O. (2009). What impact will climate change have on rural groundwater supplies in Africa? Hydrological Sciences Journal-Journal Des Sciences Hydrologiques, 54(4), 690-703. doi: DOI 10.1623/hysj.54.4.690

MAHRH/MS. (2005). Arrêté Conjoint n00019/MAHRH/MS du 5 avril 2005 portant définition des normes de potabilité de l'eau. Ministère de l'Agriculture, de l'Hydraulique et de Ressources Halieutiques du Burkina Faso, Ministère de la Santé du Burkina Faso. Retrieved 01.11.2016, from

http://www.legiburkina.bf/m/Sommaires JO/Arr\%C3\%AAt\%C3\%A9 conjoint MAHRH MS 2 005 00019.htm

Martin, N., \& Van De Giesen, N. (2005). Spatial distribution of groundwater production and development potential in the Volta River basin of Ghana and Burkina Faso. Water International, 30(2), 239-249.

Milési, J. P., Ledru, P., Feybesse, J. L., Dommanget, A., \& Marcoux, E. (1992). Early proterozoic ore deposits and tectonics of the Birimian orogenic belt, West Africa. Precambrian Research, 58(1-4), 305-344.

Naujokas, M. F., Anderson, B., Ahsan, H., Aposhian, H. V., Graziano, J. H., Thompson, C., \& Suk, W. A. (2013). The Broad Scope of Health Effects from Chronic Arsenic Exposure: Update on a Worldwide Public Health Problem. Environmental health perspectives, 121(3), 295-302. doi: 10.1289/ehp.1205875

Nikiema, J., Gläßer, W., Krieg, R., \& Schirmer, M. (2013). Trace elements and their correlations in hand-dug wells in a laterite environment in a semi-arid region: Case study of Tikaré, Northern Burkina Faso. Environmental Earth Sciences, 69(7), 2393-2414.

Nikiema, J., Schirmer, M., Gläßer, W., \& Krieg, R. (2010). Correlative and comparative characterization of main ion concentrations in laterite groundwater in semi-arid northern Burkina Faso. Environmental Earth Sciences, 61(1), 11-26.

Nolan, B. T., \& Hitt, K. J. (2006). Vulnerability of shallow groundwater and drinking-water wells to nitrate in the United States. Environmental Science and Technology, 40(24), 7834-7840. doi: 10.1021/es060911u

Nolan, B. T., Hitt, K. J., \& Ruddy, B. C. (2002). Probability of nitrate contamination of recently recharged groundwaters in the conterminous United States. Environmental Science and Technology, 36(10), 2138-2145. doi: 10.1021/es0113854

Nzihou, J. F., Bouda, M., Hamidou, S., \& Diarra, J. (2013). Arsenic in drinking water toxicological risk assessment in the north region of Burkina Faso. Journal of Water Resource and Protection, $5(8 \mathrm{~A}), 46$.

Ouedraogo, I., Defourny, P., \& Vanclooster, M. (2016). Mapping the groundwater vulnerability for pollution at the pan African scale. Science of the Total Environment, 544, 939-953. doi: 10.1016/j.scitotenv.2015.11.135 
Ouédraogo, O., \& Amyot, M. (2013). Mercury, arsenic and selenium concentrations in water and fish from sub-Saharan semi-arid freshwater reservoirs (Burkina Faso). Science of the Total Environment, 444, 243-254.

Ouedraogo, S. B. E. (2016). Étude du fonctionnement d'un procédé de traitement de l'arsenic par adsorption sur oxyde de fer. (Unpublished Master thesis), Institut International d'Ingénierie de l'Eau et de l'Environnement (2iE), Ouagadougou, Burkina Faso.

QGIS Development Team. (2015). QGIS Geographic Information System: Open Source Geospatial Foundation Retrieved from http://www.qgis.org/

R Core Team. (2015). R: A language and environment for statistical computing. Vienna, Austria: R Foundation for Statistical Computing. Retrieved from http://www.R-project.org/

Rodríguez-Lado, L., Sun, G., Berg, M., Zhang, Q., Xue, H., Zheng, Q., \& Johnson, C. A. (2013). Groundwater arsenic contamination throughout China. Science, 341(6148), 866-868.

Sako, A., Bamba, O., \& Gordio, A. (2016). Hydrogeochemical processes controlling groundwater quality around Bomboré gold mineralized zone, Central Burkina Faso. Journal of Geochemical Exploration, 170, 58-71. doi: 10.1016/j.gexplo.2016.08.009

Salifu, A., Petrusevski, B., Ghebremichael, K., Buamah, R., \& Amy, G. (2012). Multivariate statistical analysis for fluoride occurrence in groundwater in the Northern region of Ghana. Journal of Contaminant Hydrology, 140-141, 34-44.

Schlüter, T. (2008). Geological atlas of Africa: Springer.

Shamsudduha, M., Taylor, R. G., \& Chandler, R. E. (2015). A generalized regression model of arsenic variations in the shallow groundwater of Bangladesh. Water Resources Research. doi: 10.1002/2013WR014572

Singh, S. K., \& Vedwan, N. (2015). Mapping composite vulnerability to groundwater arsenic contamination: an analytical framework and a case study in India. Natural Hazards, 75(2), 1883-1908. doi: 10.1007/s11069-014-1402-2

Smedley, P. L. (1996). Arsenic in rural groundwater in Ghana. Journal of African Earth Sciences, 22(4), 459-470.

Smedley, P. L., Knudsen, J., \& Maiga, D. (2007). Arsenic in groundwater from mineralised Proterozoic basement rocks of Burkina Faso. Applied Geochemistry, 22(5), 1074-1092.

Smith, A. H., Lingas, E. O., \& Rahman, M. (2000). Contamination of drinking-water by arsenic in Bangladesh: a public health emergency. Bulletin of the World Health Organization, 78(9), 1093-1103.

Somé, I., Sakira, A., Ouédraogo, M., Ouédraogo, T., Traoré, A., Sondo, B., \& Guissou, P. (2012). Arsenic levels in tube-wells water, food, residents' urine and the prevalence of skin lesions in Yatenga province, Burkina Faso. Interdisciplinary Toxicology, 5(1), 38-41.

Sorichetta, A., Ballabio, C., Masetti, M., Robinson, G. R., \& Sterlacchini, S. (2013). A comparison of data-driven groundwater vulnerability assessment methods. Groundwater, 51(6), 866-879. doi: 10.1111/gwat.12012

UNDP. (2015). Human Development Report 2015. New York, USA: United Nations Development Programme.

UNICEF. (2008). UNICEF handbook on water quality. United Nations Childrens Fund, New York/USA.

UNICEF and World Health Organization. (2015). Progress on sanitation and drinking water: 2015 update and MDG assessment. Geneva: World Health Organization (WHO).

Van Geen, A., Zheng, Y., Versteeg, R., Stute, M., Horneman, A., Dhar, R., Steckler, M., Gelman, A., Small, C., Ahsan, H., Graziano, J. H., Hussain, I., \& Ahmed, K. M. (2003). Spatial variability of arsenic in 6000 tube wells in a 25 km2 area of Bangladesh. Water Resources Research, 39(5), HWC31-HWC316.

Verplanck, P. L., Mueller, S. H., Goldfarb, R. J., Nordstrom, D. K., \& Youcha, E. K. (2008). Geochemical controls of elevated arsenic concentrations in groundwater, Ester Dome, Fairbanks district, Alaska. Chemical Geology, 255(1-2), 160-172. doi: 10.1016/j.chemgeo.2008.06.020

Walker, F. P., Schreiber, M. E., \& Rimstidt, J. D. (2006). Kinetics of arsenopyrite oxidative dissolution by oxygen. Geochimica et Cosmochimica Acta, 70(7), 1668-1676. doi: 10.1016/j.gca.2005.12.010 
WHO. (2011). Guidelines for drinking-water quality. Geneva, Switzerland: World Health Organization

Winkel, L., Berg, M., Amini, M., Hug, S. J., \& Annette Johnson, C. (2008). Predicting groundwater arsenic contamination in Southeast Asia from surface parameters. Nature Geoscience, 1(8), 536-542.

Winkel, L. H. E., Trang, P. T. K., Lan, V. M., Stengel, C., Amini, M., Ha, N. T., Viet, P. H., \& Berg, M. (2011). Arsenic pollution of groundwater in Vietnam exacerbated by deep aquifer exploitation for more than a century. Proceedings of the National Academy of Sciences of the United States of America, 108(4), 1246-1251.

Yang, Q., Culbertson, C. W., Nielsen, M. G., Schalk, C. W., Johnson, C. D., Marvinney, R. G., Stute, M., \& Zheng, Y. (2015). Flow and sorption controls of groundwater arsenic in individual boreholes from bedrock aquifers in central Maine, USA. Science of the Total Environment, 505, 12911307. doi: 10.1016/j.scitotenv.2014.04.089

Yang, Q., Jung, H. B., Marvinney, R. G., Culbertson, C. W., \& Zheng, Y. (2012). Can arsenic occurrence rates in bedrock aquifers be predicted? Environmental Science and Technology, 46(4), 20802087.

Yuan, Y., Marshall, G., Ferreccio, C., Steinmaus, C., Liaw, J., Bates, M., \& Smith, A. H. (2010). Kidney Cancer Mortality Fifty-year Latency Patterns Related to Arsenic Exposure. Epidemiology, 21(1), 103-108. doi: 10.1097/EDE.0b013e3181c21e46

Yuan, Y., Marshall, G., Ferreccio, C., Steinmaus, C., Selvin, S., Liaw, J., Bates, M. N., \& Smith, A. H. (2007). Acute myocardial infarction mortality in comparison with lung and bladder cancer mortality in arsenic-exposed region II of Chile from 1950 to 2000. American Journal of Epidemiology, 166(12), 1381-1391. 